\title{
Two approaches to the myth of city foundations: Syntagmatic and paradigmatic
}

\author{
Kestutis Nastopka \\ Greimas Centre for Semiotic Studies, University of Vilnius \\ Universiteto 3, 2734 Vilnius, Lithuania \\ e-mail: kestutis@osf.lt
}

\begin{abstract}
The paper discusses the myth of the founding of Vilnius as an example of a myth of city foundation. The myth has received two independent semiotic interpretations. Narrative grammar procedures are applied to the analysis of the mythical story and the semantic code generating the story in the paper "Gediminas' Dream (Lithuanian myth of city foundation: an attempt at analysis)" by Algirdas Julien Greimas (1971). The sovereignty ideology expressed in the myth, which describes religious and spiritual culture of the Grand Duchy of Lithuania, is linked to the tri-functional model of the IndoEuropean social structure. The semantics of the Vilnius myth is seen as analogous with such Indo-European myths as king's accession to the throne and creation of a city-state. The Lithuanian myth of Vilnius is linked paradigmatically to the Indo-European mythology in the study "Vilnius, Wilno, Vil'na: City and myth" by Vladimir Toporov (1980). At the level of the signifier, phonological equivalents of toponyms of Vilnius are traced. At the level of the signified, transformations of the "core" Indo-European myth are identified. The myth of the city foundation can be read both as a figurative form of cultural expression and as an ideology narrated as a plot of a story. In this view, the paradigmatic and syntagmatic approaches complement each other.
\end{abstract}

The phenomenon of the city, which appeared as a result of the neolithic revolution, marks man's transition from beyond the cosmological natural existence into the historical existence. The fragile balance of the good and the evil is replaced in the city life by a series of disjunctions and conjunctions of the individual and society. The function of city myths is to reconstruct the contract between the man, who is in charge of his own living conditions, and the transcendental Addresser, and to re-assert the victory of cosmos over chaos. 
The myth of city foundation, through a historically set plot, gives a miniature model of the world. In this respect it can be regarded as the underlying political myth of a nation and can be compared with the story of the fight between Thunder and his opponent, which is regarded by Vyacheslav Ivanov and Vladimir Toporov as the core IndoEuropean cosmogonical myth (Ivanov, Toporov 1974: 3, 164). In the Lithuanian political mythology, this position is taken by the myth of the founding of the city of Vilnius, which was first recorded in the sixteenth century Annals.

Lithuanian Annals (Jasas 1971: 71-72) contain a story of two hunting trips of Duke Gediminas. On his first hunting trip, Gediminas leaves the Old Capital Kernavė and finds himself in an oak forest on a beautiful hill, where he founds a city Trakai, and where he moves the Capital. On his second hunting trip, Gediminas leaves the Capital Trakai and finds himself on a beautiful hill by the river Vilnia, where he kills a huge taurus (the hill since then has been called the Taurus Hill). Gediminas stays for the night in the Šventaragis Valley, and in his dream he sees a huge wolf standing on the Crooked Hill, and inside the wolf there could be heard a howling of a hundred of wolves. The pagan priest Lizdeika (whose name derives from the Lithuanian word lizdas, English nest, because he was found in an eagle's nest) gives an interpretation of the Gediminas' dream: the Iron Wolf means that a Capital-City will be found here, and a howling inside the wolf means that the fame of the Capital-City will spread all over the world. The next morning the Duke Gediminas builds a Lower Castle in the Šventaragis Valley and an Upper Castle on the Crooked Hill. He gives the name of Vilnius to these Castles and moves the capital to Vilnius. As the Annals suggest, after founding Vilnius, Gediminas ruled the Dutchy of Lithuania for many years, was a just duke, won many wars, and was a happy ruler until his old age.

Another version of the myth, with a broader historical and religious commentary, is offered by the Polish chronicler Maciej Stryjkowski (1846: 369-373). In his story about the increasing worshiping of gods in the newly-founded Capital-City, he identifies three key places of cult. The first one is in the Šventaragis Valley, where eternal fire is burned by the mythical Šventaragis, the first Grand Duke of the Grand Dutchy of Lithuania, who established the custom of burning bodies of the deceased. This cult is compared by Stryjkowski to the cult of the temple of Vesta in Rome. The second one is the place of cult of the Fire of Perkünas established by Gediminas. According to Stryjkowski, he "built a monument for Perkūnas: a figure, holding in 
his hand a huge piece of flintstone with which priests produced fire; the eternal fire sacrificed to him was burned day at night and kindled with oak wood." The third place of worship set up by Gediminas is on the outskirts of the city: Gediminas "gives the dark forests to the gods and, following the pagan custom, inhabits them with priests so that they could pray for the souls of the dukes and breed and feed the Snakes as the gods of the Home". Lizdeika is announced the Chief Pagan Bishop of all the cults.

The myth of Vilnius foundation has received two independent semiotic interpretations. The first, an article by Algirdas Julien Greimas entitled "Gediminas' Dream (Lithuanian myth of city foundation: an attempt at analysis)", written in French in about 1971, has remained in its manuscript form. The Lithuanian translation of the article was published in 1998 (Greimas 1998). The second one, a study by Vladimir Toporov entitled "Vilnius, Wilno, Vil'na: the city and the myth", was published in 1980 (Toporov 1980). Greimas, at the time of writing this article, was not familiar with Ivanov and Toporov's investigations of Baltic and Slavic mythology. Toporov, in his own turn, was not familiar with Greimas' manuscript.

In Toporov's analysis, the point of departure is binary spacial opposition which correlates with value oppositions of life vs death and sacral vs profane. The historical existence of the city is given significance through the "heavenly blessing from the above and the blessing from down below in the valley". Toporov sees the myth of city foundation as a transformed version of the cosmogonical myth. In this view, positive forces from "the above" are associated with the god Perkünas, the taurus, the horn, and the eagle; negative forces from the "down below" are associated with the opponent of Perkünas, which in the myth appears as the Snake and the Velnias (the pagan ruler of the Underworld) as well as the element of water. The figure of the Wolf performs the function of the mediator. As a chtonic animal, the Wolf is associated with the bottom of the hill (this is supported by the toponymy of Vilnius) and is opposed to the Eagle. However, in Gediminas' dream, the Iron Wolf appears at the top of the hill and thus signifies the military sovereignty protected by god Perkūnas.

Gediminas is seen by Toporov as an epic transformation of Perkünas, and the blacksmiths who made the Iron Wolf are seen as the workmen of Perkunas. In the value opposition of above vs down below, the role of the opponent of Perkūnas is given to the river Vilnia, which is compared to a wrigling snake. According to the logic of the myth (Thunder strikes dragon or the snake and kills it), the hero 
who destroys the monster is the founder of a city (a new universe) and the creator of Cosmos out of Chaos. The river-snake analogue is also traced in reference to the Snakes which are worshipped by priests in dark forests.

Toporov looks for phonological counterparts of Vilnius toponymy in the mythological Indo-European terms. In the Indo-European root *vel-, from which the name of the river (Vilnia) and the city (Vilnius) derives, two semantic poles are identified: "the down below", chtonic, death vs "the abow", life, fertility, power. A mythical mediation of meaning takes place between these two poles.

The motif of the twins, characteristic of city foundation myths, is traced by Toporov in the double name of pagan priest Krive-Krivaitis. A hypothesis is made that a double name indicates the presence of a twin-brother who was sacrificed in the name of the city. The pattern of twins is applied in order to reconstruct the social structure of the prehistoric Vilnius. A Slavic element is discerned in the toponymy of Vilnius, which is identified in the root of the word Krivis. It is linked by Toporov to the semantics and the magic function of kreivas (crooked) and kairys (left-handed). In the Vilnius myth, Toporov sees a synthesis of two opposite ethnic and social elements.

Algirdas Greimas in his analysis of the Vilnius myth, applies procedures of narrative grammar. The duplification of hero's departure and quest is considered to be a specific feature of the Vilnius story. The first trip resulting in the foundation of Trakai turns out to be insufficient. The second trip — the foundation of Vilnius — is successful due to an embedded sequence related to events such as the hunting of Taurus and the dream of Gediminas. The successful hunt of Taurus is interpreted as the qualifying test of the hero. The dream of Gediminas, as a message sent by the gods predicts the decisive test, that is, the founding of the city, and the glorifying test, that is, the future glory of Vilnius. The quest of the city founder turns out to be a quest for a contract with the gods.

The modal structure of the Lithuanian myth distinguishes it from analogical Indian or Roman myths, where the implicit approval of the gods is prior to the contract between the ruler and the nation. As he departs, Gediminas is already a sovereign. He founds the city of Trakai by his pragmatic power of an earthly ruler. But only through the hunting of the Taurus, the founder of Vilnius acquires the cognitive competence of the divine knowing.

The ideological content of the myth is discussed by Greimas in two respects: as the king's accession to the throne and as the creation of 
the City-State. This distinction of the ideological content is evident in the distinction between the mythical figures: Greimas perceives the figurative language of the myth as a compromise between the individual freedom and the social need for communication (Greimas 1990: 30).

Greimas does not rely on the phonological counterparts and, therefore, looks for parallels between Lithuanian myths and the analogous Indo-European myths at the level of the signified. The thematic value of the Taurus figure is compared to the Iron Cow in a Lithuanian magic tale, as well as to the counterpart figures in the Roman myths (the Imperial Cow), the Indian myths (the Cow of Plenty), the Irish myths (the Wooden Cow of King Bress), all of which signify recognition of the King or disqualification of the King.

The figure of the Iron Wolf embodies the power of the future capital. It can be compared to the Roman She-Wolf who fed the future founders of the city. The change of the gender of the Wolf and the epithet "iron", which reminds us of the Iron Cow of the Lithuanian magic tale, implies that the Iron Wolf is not a simple genetic borrowing.

Like Toporov, Greimas recognizes a trace of the Twins myth in the Vilnius myth, but he gives it a syntagmatic interpretation. To give a mythical justification to the sovereignty of the ruler, it is necessary to have two brothers who are foundlings (this marks a new beginning) and one of whom is murdered to leave a "sole" ruler. In the Vilnius story, the mythical twin-brother of Gediminas is the pagan priest Lizdeika who was found in an eagle's nest, by the Duke Vytenis who brought him up like his own son. In the Annals, Gediminas is considered to be Vytenis' son. The motif of murder appears in the "Polish Chronicle" by Miechowita, which holds that Gediminas was Vytenis' horse-groom and that he came to power by killing his master. The two different versions of the myth, regardless of the "historical truth", appropriate patches of the "mythical truth" each in their own way.

According to Greimas, the meanings of the Vilnius story are articulated by crossing binary structures, characteristic of mythical reasoning and tri-partite division characteristic of the form of mythical narrative. The tri-partite division is established by the three marked narrative spaces (two hills and one valley), three mythical events (the hunting of the Taurus, the dream of Gediminas and the appearance of the Iron Wolf), and three places of cult within the boundaries of Vilnius. The binary structure, supported by the historical elements and 
the narrative elements does not overshadow the tri-partite justification of the Holiness.

In the structure of the Baltic religion, Greimas recognizes a modified, tri-functional model of the Indo-European social structure. In his mythological research, the first function of Dumézil is divided into an independent juridical sovereignty (which takes the domain of the third function, that of wealth, fertility and health), and a magical sovereignty. Only the second - military - function retains its traditional mode (Greimas 1985: 129-135).

In the Vilnius myth, the heavenly juridical sovereignty is linked by Greimas to the God Moon who is later treated as a degraded form of Andojas, the ruler of the Water World, the real world. The God Moon's cult is practiced by the priests, aboding in the dark forest and protecting the Snakes. The magical sovereignty is linked to the cult of Eternal Fire in the Šventaragis Valley. Greimas discerns the figure of the underworld god Velnias, who is counterpart of Christian Devil, or the figure of Kalvis (Blacksmith), Lithuanian Volcano who replaced Velnias after the religious revolution (which established the sacrificial burning of the deceased bodies). (Blacksmiths, as suggested above, are considered by Toporov as workmen of Perkūnas). The military function is ascribed by Greimas, as well as Toporov, to Perkūnas whose cult was established by Gediminas.

The primary elements, water and fire, fall into tri-partite distinction as well. Linked to the spacial opposition of above vs down below, they are divided into high waters vs low waters and high fire vs low fire. All the waters belong to the domain of the Moon, therefore, high waters and low waters co-exist in harmony and cooperation. Whereas high fire, which belongs to the domain of Perkūnas, and low fire, which belongs to the domain of the Underworld Ruler, are in opposition and cannot be reconciled. Within the semiotic square, the Moon and the Perkünas (which substitute one another) are seen in a relation of contrariety, while the Velnias and the Perkünas (which annihilate one another) are seen in a relation of contradiction.

In terms of human powers, the juridical sovereignty is represented by Gediminas. The Annals describe him as a just Duke who ruled happily until his old days. Greimas, following Dumézil, ascribes the mythical Gediminas to the Lunar dynasties and opposes him to the Solar dynasties which include rulers living in "fury and blood". The military sovereignty is ascribed by the Annals to the mythical Goštautas whose name suggests that he ruled the nation (Lith. gožti 
means to rule). The magical sovereignty and the cult of Underworld God is represented by Lizdeika.

The Vilnius myth found its way into the Annals and became popular most likely because it was in line with the political ideology of the 16th century Lithuanian nobility who tried to retain their power and independence. Moreover the writers of the Annals, allthough they were Christians, unconsciously recorded the pagan religious ideology which was alien to them. Within this ideology, Gediminas' sovereignty is a direct expression of the will of the old gods. A special attention paid by Gediminas to the caste of pagan priests demonstrates his efforts to establish a high status of the old religion after the religious and political unrest in the second half of the 13th century. In this respect, Greimas compares Gediminas myth to Indian and Roman myths, where founders of new kingdoms blame their predecessors for "destroying the castes" and breaching the rights of the religious class.

In their analyses of the same texts, Toporov and Greimas reach different conclusions. Binary classificatory logic enables Toporov to identify in the Lithuanian myth universal symbolic configurations, modelling the world structure and producing its various transformations. The Vilnius myth is read as a permanent struggle between Cosmos and Chaos and as a continuous chain of deaths and births. The events of earthly life find their reflection in the transcendental world, which has at its center the figure of Perkünas - advocate of change and the keeper of the cosmic order. Gediminas appears as a wordly counterpart of Perkūnas, Lizdeika - as a pagan priest of Perkūnas, and the Taurus and Iron Wolf appear as zoomorphic metonyms of Perkünas. This reading gives the myth features of a piece of art and produces a deep aesthetic impression. Binary logic is more difficult to apply to the historical epochs which are characterized by competition of various ideological forms. The presence of two ethnic entities in the prehistory of Vilnius, reconstructed by Toporov by linguistic instruments, is highly probable. However, what does it mean within the ideology of the myth?

Greimas approaches the myth of Vilnius as a syntagmatic narrative with a marked beginning and a marked ending. He combines the binary principle with tri-partite structure of the old Lithuanian religion. This radically changes the functions of both transcendental deities and their earthly counterparts. The militant Perkūnas ceases to be the only heavenly sovereign and gives the duty of protecting the founder of Vilnius to the deity of juridical sovereignty. The role of the earthly counterpart of Perkūnas is given to Goštautas (who was of no 
interest to Toporov). An independent type of magical sovereignty, is represented by the pagan priest Lizdeika. The Indo-European context of Vilnius myth is described at the level of the signified, rather than at the level of the signifier. Figures are identified which in Indian, Roman and Germanic myths manifest the ideology of the king's accession to the throne and the power of the city.

Despite their common semiotic orientation, Toporov and Greimas use different methodological approaches. Behind the logic of binary classification is the view of mythology as an articulation of the general cultural philosophy. This view was established and developed by Claude Lévi-Strauss. In his analysis of mythologies of archaic communities, he discerns axiological systems and distinguishes basic oppositions, in terms of which a community reflects its own culture (Lévi-Strauss 1964-1971). On the other hand the approach to mythology as a syntactic articulation of values is linked to the name of Georges Dumézil. In his analysis of relatively developed Indo-European class communities, he looks in their myths, for an ideology, which enables the community to understand itself and its contradictory founding forces, as well as the relationship between the earthly sovereign and the godly one (Dumézil 1986). In this view, myth appears as an actant structure, which actualizes the values selected from a virtual axiological system and which gives these values a figurative form.

Lithuanian mythology can be read both paradigmatically, in the "American-Indian" way (following Lévi-Strauss), and syntagmatically, in the "Roman" way (according to Dumézil). From the ethnographic materials collected in the 19th century, mythologists are trying to reconstruct the customs and rituals, characteristic of a closed, archaic, rural community, and the relics of old beliefs covered by a Christian film of dust. However, there exists another layer of Lithuanian mythology, recorded in relatively few written sources of earlier times, which represents a religion practiced by a united Lithuanian community before the adoption of Christianity. This ideology of sovereignty, solid and stiff is likely to account for the expansion of the Lithuanian State in the 13th-14th centuries, something, which cannot be explained either by demographic or economic reasons.

Taking only one of the two methodological approaches makes it hardly possible to reconstruct a totality of the mythological images, of specific historical epoch, a totality which consists of contradictory heterogeneous elements. It is important to describe the ideology and culture of any historical epoch, as an autonomous semantic world. The 
myth of the city foundation can be read both as a figurative form of cultural expression and as an ideology narrated as a plot of a story. In this view, the paradigmatic and syntagmatic approaches complement each other.

\section{References}

Dumézil, Georges 1986. Les dieux souverains des Indo-Européens. Paris: Gallimard.

Greimas, Algirdas Julien 1985. Des dieux et des homes: études de mythologie lithuanienne. Paris: PUF.

- 1990. Tautos atminties beieškant. Apie dievus ir žmones. Vilnius: Mokslas.

- 1998. Gedimino sapnas (lietuvių mitas apie miesto ikūrimą: analizès bandymas). Kultūros barai 8/9: 65-75.

Ivanov, Vyacheslav V.; Toporov, Vladimir 1974 = Иванов, Вячеслав; Топоров,

Владимир. Исследования в области славянских древностей. Москва: Наука.

Jasas, Rimantas (ed.) 1971. Lietuvos metraštis (Bychovco kronika). Vilnius: Vaga. Lévi-Strauss, Claude 1964-1971. Mythologiques. 1-4. Paris: Plon.

Stryjkowski, Maciej 1846. Kronika Polska, Litewska, Żmódzka I wszystkiej Rusi. 1. Warszawa: Glücksberg.

Toporov, Vladimir 1980 = Топоров, Владимир. Vilnius, Wilno, Вильна: город и миф. In: Балто-славянские этноязыковые контактыл. Москва: Наука, 3-71.

\section{Два подхода к мифу об основании города: синтагматика и парадигматика}

В данной статье миф о создании Вильнюса рассматривается как образец мифа об основании города. Этот миф стал предметом двух самостоятельных семиотических интерпретаций. Альгирдас Жюльен Греймас в статье «Сон Гедиминаса (литовский миф об основании города: попытка анализа)» (1971) применяя процедуры нарративной грамматики раскрывает семантический код, генерирующий мифическое повествование. Миф, преставляющий религиозную и духовную культуру Великого Княжества Литовского, выражает идеологию суверенности, соотносимую с трехфункциональной моделью индоевропейской социальной структуры. Семантика Вильнюсского мифа сопоставляется с семантикой индоевропейских мифов, рассказывающих о восхождении короля на престол и о сотворении города-государства. В исследовании Владимира Николаевича Топорова «Vilnius, Wilno, Вильна: город и миф» (1980) 
миф о создании Вильнюса соотносится с индоевропейской мифологией парадигматически. На уровне сигнификантов прослеживаются фонологические эквиваленты Вильнюских топонимов. На уровне сигнификатов отмечается трансформация «основного» индоевропейского мифа. Миф о создании города можно читать либо как фигуративную форму выражения культуры, либо как идеологию, поданную в форме повествования фабульной истории. В этом смысле парадигматический и синтагматический подходы дополняют друг друга.

\section{Kaks lähenemist linnaloomise müüdile: süntagmaatika ja paradigmaatika}

Müüti Vilniuse loomisest vaadeldakse siin kui linnaloomise tüüpmüüti. Seda müüti on käsitletud kahes iseseisvas semiootilises interpretatsioonis. Algirdas Greimas toob artiklis "Gediminase uni (leedu linnaloomismüüt: analüüsi katse)" (1971) narratiivse grammatika protseduure kasutades välja müütilist jutustust genereeriva semantilise koodi. Müüt, mis esindab Leedu Suurvürstiriigi religioosset ja vaimset kultuuri, väljendab suveräänsuse ideoloogiat, mis on ühildatav indoeuroopa sotsiaalse struktuuri kolmfunktsionaalse mudeliga. Vilniuse müüdi semantikat võrreldakse indoeuroopa müütide, mis jutustavad kuninga troonile asumisest ja linnriigi loomisest, semantikaga. Vladimir Toporovi uurimuses "Vilnius, Vilno, Vilna: linn ja müüt" (1980) seostatakse Vilniuse loomismüüti indoeuroopa mütoloogiaga paradigmaatiliselt. Tähistajate tasandil on jälgitavad Vilniuse toponüümide fonoloogilised ekvivalendid. Tähistatavate tasandil märgitakse ära indoeuroopa "põhimüüdi" transformatsioon. Linnaloomismüüti võib lugeda kui figuratiivset kultuuri väljendusvormi või kui ideoloogiat, mis on esitatud faabulaga loo jutustavas vormis. Selles mõttes täiendavad paradigmaatiline ja süntagmaatiline lähenemine teineteist. 